\title{
How Can QE3 Affect the Housing Market?
}

\author{
Carlos Garriga, Research Officer and Economist
}

$\mathrm{T}$ he Federal Open Market Committee (FOMC) recently announced a third round of quantitative easing (QE3) involving the purchase of agency mortgage-backed securities at a pace of $\$ 40$ billion per month. The FOMC also announced that it anticipated the exceptionally low levels for the federal funds rate would prevail at least through mid-2015. According to the FOMC's September statement, the QE3 objectives are to (i) put downward pressure on longer-term interest rates and hence support mortgage markets, (ii) assist in making broader financial conditions more accommodative, and (iii) foster employment growth. ${ }^{1}$ These goals are more ambitious than those for the QE1 and QE2 programs, which were undertaken when it appeared likely that inflation would fall below the FOMC's target. However, this is not the case with QE3, which seems to be focused more on hastening the recovery of the economy. This essay describes the recent housing market landscape and where QE3 can (and cannot) help.

The Fed's concern for housing markets and mortgage rates is a relatively new phenomenon and is partially a result of the real estate price bubble that burst in the mid2000s. Historically, house price bubbles have been localized and affected only areas with rapid economic growth or migratory flows. The latest housing bust, however, was a nationwide problem with important ramifications for employment and economic activity.

Housing booms and busts are not new to the United States, but there has not been a bust of this magnitude since the Great Depression. During the boom and bust years between 1915 and 1933, only 43 percent of the population owned the home they occupied, which is low compared with the current ownership rate of 66 percent. The majority of these pre-World War II homeowners had short-term mortgage loans (5 to 10 years) with no amortization. Most loans were balloon mortgages that had to be refinanced frequently because of their short duration. With the collapse of the banking sector during the Depression, many homeowners could neither refinance nor sell their homes, which generated a large number of foreclosures.
The recovery from the Great Depression was slow and very different from a traditional business cycle. Recoveries from recessions associated with housing busts are usually slow and weak. The weakness can be attributed to the slow process of deleveraging that must occur before consumer spending can grow rapidly. After the collapse of mortgage markets, government intervention provided uniform lending standards throughout the country that resulted in low and stable mortgage rates. The result was a postwar boom in house prices and homeownership.

\section{The Fed's concern for housing is a relatively new phenomenon.}

Historically, house price bubbles have been localized and affected only areas with rapid growth. The latest housing bust, however, was a nationwide problem with important ramifications for employment and economic activity.

The postwar housing boom solidified the idea that house prices would never decline again. During the recent housing boom, more first-time buyers had access to the housing market than ever before; others took advantage of real estate appreciation and moved to larger homes or borrowed against their home equity. Real estate developers competed with each other for available plots of land, bidding up the price of land. Household debt rose rapidly, and most of the increase in total domestic debt was household real estate debt. Between 2000 and 2006, mortgage debt represented 40 percent of U.S. gross domestic product. When house prices subsequently declined by 30 percent, this figure grew to 62 percent.

The collapse of the housing market left many households highly leveraged and the construction sector facing sharply reduced demand for new homes amid a large 
inventory of unsold homes. The economy is still trying to absorb the large numbers of unemployed workers affected by the collateral damage of the housing boom.

The process of household deleveraging - that is, reducing levels of debt relative to income-is usually slow. Households' incomes are insufficient to repay their debts. The size and duration of this adjustment could affect the economy's ability to recover and, conceivably, the nation's long-term economic growth. For instance, the contribution of the construction sector and related activities to growth will likely remain low because of the large stock of housing inventory. As a result, estimates of potential growth might need to be revised down. In addition, high unemployment further slows growth, reducing the ability of households to deleverage. When the economy is in a process of deleveraging, it cannot grow as rapidly as it might otherwise because consumer spending is constrained. Consumers reduce spending because more of their income is diverted to paying off their debts.
The Fed's QE3 policy may do little to help the 23 percent of homeowners (11.1 million) who are currently underwater-owing more on their mortgages than their homes are worth-but it could allow the remaining 77 percent (48.3 million) with positive equity and stable jobs to refinance their mortgages at lower interest rates. QE3 should also provide funding for renters or investors to purchase part of the existing stock of homes. This support should stimulate consumption spending and house prices could increase. Then, troubled homeowners should be able to refinance their loans to better terms and adjust their consumption expenditure. Ultimately, the impact of QE3 on the housing market and the real economy will be tied to the deleveraging process and the recovery of the housing market. This could be a lengthy process, so patience is needed before the success of the QE3 program can be evaluated.

\section{Note}

${ }^{1}$ Federal Open Market Committee statements can be found at www.federalreserve.gov/newsevents/press/monetary/20120913a.htm. 